\title{
Bulancak İlçesinde Tarımsal İşletmelerin ve Üretim Faaliyetlerinin İncelenmesi ${ }^{\dagger}$
}

\author{
Derya ÖZTÜRK ${ }^{*}$ \\ Ali İSLAM ${ }^{\dagger}$ \\ Ali TURAN \\ Malik Arsal KÖSE
}

$\ddot{O} \mathbf{z}$

Bu çalışmada, Giresun ili Bulancak ilçesinde tarımsal işletmelerin ve üretim faaliyetlerinin mevcut durumu incelenmiş ve öneriler yapılmıştır. Araştırmada kullanılan veriler, 2016-2017 üretim döneminde 10 köyden tabakalı tesadüfi örnekleme yöntemi ile seçilen 134 işletmeden anket yöntemi ile elde edilmiştir. İşletmeler sahip oldukları arazi büyüklüklerinin frekans dağılımına göre üç gruba ayrılmıştır. Araştırma sonuçlarına göre; işletme başına düşen ortalama işletme arazisi 1. grupta 5,02 da, 2. grupta 15,76 da, 3. grupta 45,80 da ve işletme genel ortalamasında ise 24,29 da olarak bulunmuştur. Her üç grupta da tarım arazilerinin çok büyük bir kısmını fındık bahçeleri oluşturmaktadır. Fındık arazilerini sırasıyla diğer meyveler, tarla bitkileri, sebzeler, çayır-mera ve çalılık-ağaçlık arazi izlemektedir. İşletmelerde tarım faaliyetlerinde karşılaşılan en önemli kısıtlar sırasıyla; düşük satış fiyatı, pahalı tarım girdileri, hastalık, düşük verim ve işgücü yetersizliği şeklinde sıralanmaktadır. Tarım faaliyetlerini geliştirmek için işletmeler daha fazla bilgilenmeye çalıştıklarını, il/ilçe tarım görevlilerine danıştılarını, kooperatife/birliğe üye olduklarını ve kredi aldıklarını belirtmişlerdir. İşletmeler tarımla ilgili sorunlarını bilgili çiftçilere, arkadaşlarına/meslektaşlarına, tarım teşkilatı uzmanlarına danışarak çözmektedirler. Verim ve kalitenin artırması ve üretim maliyetlerinin düşürülmesi bakımından yeter işletme büyüklüğü ve modern tarım tekniklerinin yerinde ve zamanında uygulanması önerilmektedir. Ayrıca son zamanlarda daha da değer kazanan çiftçilik mesleği ve gıda üretiminin önemi de vurgulanmaktadır.

Anahtar Kelimeler: İşletme, Üretim, Fındık, Tarım, Bulancak

\section{Examination of Agricultural Enterprises and Production Activities in Bulancak}

Abstract

In this study, the current state of agricultural enterprises and production activities in Bulancak District of Giresun province was examined and some suggestions was made. Data were collected from 134 enterprises selected from ten villages using stratified random sampling in the 2016-2017 production period. The data were collected using the survey method. The enterprises were divided into three groups based on the frequency distribution of the size of land that they had. According to the results, Groups 1, 2, and 3 had an average of 5.02 decare, 15.76 decare, and 45.80 decare agricultural lands per enterprise, respectively. The overall average was 24.29 decare. In all groups, most of the agricultural lands were hazelnut gardens, followed by fruits, field crops, vegetables, meadow-pasture, and shrubland-woodland. The greatest problems faced by the enterprises during agricultural activities were low selling price, expensive agricultural inputs, disease damages, low yield, and scarce labor. The enterprises stated that they tried to obtain more information, consulted with agricultural provincial/district officials, became members of cooperatives/unions, took loans to improve their agricultural activities. They stated that they solved agricultural problems by consulting with knowledgeable farmers, friends/colleagues, and agricultural organization experts. In terms of increasing yield and quality and reducing production costs, it is recommended to apply sufficient business size and modern agricultural techniques. In addition, the importance of the farmer and food production, which has gained more value recently, is also emphasized.

Keyword: Business, Production, Hazelnut, Agriculture, Bulancak

Geliş/Received: 05.02.2021

Kabul/Accepted: 22.06 .2021

*Araştırmadaki anket çalışması 2016-2017 yıllarında gerçekleştirildiği için geriye dönük etik kurul izni bulunmamaktadir.

\footnotetext{
$\dagger \mathrm{Bu}$ çalışma Ordu Üniversitesi Bilimsel Araştırma Projeleri Komisyonunca kabul edilen A-1803 no’lu proje kapsamında desteklenmiştir.

* Doç. Dr., Ordu Üniversitesi, Ünye İktisadi ve İdari Bilimler Fakültesi, İşletme Bölümü, deryaozturk@odu.edu.tr Orcid: 0000-0001-5287-6600

' Prof. Dr., Ordu Üniversitesi, Ziraat Fakültesi, Bahçe Bitkileri Bölümü, islamali@ hotmail.com Orcid: 0000-0002$2165-$

‡ Doç. Dr., Giresun Üniversitesi, TBMYO, Fındık Eksperliği Programı, ali.turan@giresun.edu.tr Orcid: 0000-00022961-6605

§ Zir. Yük. Müh., Giresun İl Tarım ve Orman Müdürlüğü, malikarsal@ hotmail.com Orcid: 0000-0002-3302-0054 (Makale türü: Araştırma makalesi)
} 


\section{Giriş}

Tarım sektörünün temel görevi toplumun besin ihtiyacının karşılanması için gerekli olan gıda maddelerini üretmektir. Bunun yanında tarım sektörü, istihdam, dışsatım, sanayi sektörüne hammadde sağlayan ve iç ticarete konu olan ürünlerin üretimi açısından gelişmekte olan ülkelerde daha büyük önem taşımaktadır (Yılmaz vd., 2006: 2). Bölge kalkınmasında, tarımın ve tarımsal ürünlere dayalı sanayi üretiminin önemi büyük olmasına paralel olarak kırsal alanda nüfusun yerinde tutulması ve iyi organizasyonu da tarımsal gelirin artırılmasına önemli katk1 sağlamaktadır. Özellikle Doğu Karadeniz bölgesinde tarıma elverişli olan ya da olmayan pek çok alanda ana ürün olarak findık tarımı yapılmaktadır. Geleneksel üretim modelleri devam ettirilmekte, işletme arazileri küçük ve parçalanmış durumdadır (İslam, 2018). Söz konusu bölgeye yapılan yatırımların yetersiz ve iş olanaklarının sınırlı olması gibi nedenlerden dolayı bölge halkının ekonomik durumu olumsuz etkilenmiş ve büyük şehirlere doğru göçler gerçekleşmiştir (Öztürk ve Akçay, 2010: 62). Türkiye'de tarımda uygulanan yanlış desteklemeler, köyden kente göç vb. birçok nedenden dolayı kırsal alanlarda nüfus azalmaya başlamış ve atıl tarım arazilerinde de artış oluşmuştur. Artan nüfusun beslenmesi için gerekli olan üretim artışını gerçekleştirmek amacıyla birim alandan yüksek verim almaya çalışmak bir zorunluluk olarak karşımıza çıkmaktadır. Tarımsal üretimde verimlilik artışı, tarımın yapısı ile yakından ilişkilidir. Gerek mevcut durumun değerlendirilmesi, gerekse tarımın geliştirilmesine yönelik çalışmaların sağlıklı yürütülmesi açısından tarım sektörünün yapısına ilişkin verilerin bilinmesi ve incelenmesi önem arz etmektedir (Yılmaz vd., 2006: 2). Tarımsal verimliliği arttırmak, tarım ürünlerinin kalitesini yükseltmek ve üreticilerin gelir düzeyini istikrara kavuşturarak belli bir oranda tutmak için tarım kesimine büyük miktarlarda destek aktarmak gerekmektedir. Tarımın bu kadar çok desteklenmesinin en önemli nedeni, tarımın doğa koşullarından büyük ölçüde etkilenmesi, bu durumun da elde edilecek ürün miktarı ve kalitesi üzerinde önemli etkiler, dalgalanmalar yaratabilmesidir (Kızılaslan ve Doğan, 2013: 147).

Giresun ilinin ana geçim kaynağı tarımdır. 2019 yılı itibariyle toplam tarım alanının \%79'unda fındık tarımı yapılmakta olup, fındık üretimi yapan çiftçi aile sayısı 80 bin kişidir. Giresun ili Türkiye fındık alanının \%17'sini, üretiminin ise \%12'sini karşılayarak; Türkiye fındık üretim alanı bakımından 2., Türkiye fındık üretim miktarı bakımından ise 4.sırada yer almaktadır. Giresun ilinin toplam tarımsal üretim gelirlerinin \%82'sini bitkisel üretim gelirleri oluşturmakta, bitkisel üretim gelirlerinin de \%88-90'ını ise fındık geliri oluşturmaktadır. Bulancak ilçesi 2019 yılı itibariyle Giresun ili fındık alanının \%14'ünü, üretiminin \%13’ünü karşılayarak; Giresun fındık üretim alanı ve miktarı bakımından 2. sırada yer almaktadır. Bulancak'ta tarım sektöründe çalışanların oranı sanayi ve hizmet sektörlerinde çalışanlara oranla daha fazladır (tuik.gov.tr, 
2019). Bu açıdan bakıldığında Bulancak tarım sektörünün ekonomi içindeki payı yüksek olduğundan çalışma açısından bu ilçenin seçilmesi uygun görülmüştür.

Literatürde tarım işletmelerinin tarımsal üretim yapısına ilişkin çalışmalar bulunmakla birlikte (Bülbül, 1973; Esengün, 1990; Yıldırım, 1991; Akınc1 vd., 1997; Kasap vd., 1997; Bostan vd., 1997; Someran, 1999; Aksoyak vd., 2001; Güneş, 2004; Özden ve Armağan, 2005; İslam ve Turan, 2006; Gün ve Aksoy Dengiz, 2006; İslam, 2013; Turhan vd., 2013; Keleş, 2015; Comart, 2016; Özkan ve Kadağan, 2019; Kurnaz, 2020), Bulancak ilçesi işletmelerin tarımsal üretim yapısını ve sorunlarını inceleyerek karşılaştırma yapan çalışmalara rastlanmadığından çalışma özgün bir değere sahiptir. Diğer yandan elde edilen bulguların kamu ya da STK tarafından oluşturulacak bölgesel politikalarda yöreye özgü bir gösterge niteliğinde olacağ1 ve politika yapıcıları açısından bir kılavuz olarak değerlendirileceğidir. Ayrıca, Giresun ili Bulancak ilçesinin tarımsal üretim faaliyetinin incelenmesi ve değerlendirilmesi literatüre katk1 sağlanacaktır.

$\mathrm{Bu}$ çalışma, Giresun ili Bulancak ilçesi tarımsal işletmelerin ve üretim faaliyetlerinin işletme grupları dikkate alınarak incelenmesi amacıyla yapılmış olup mevcut durum sorunları çözüm önerileri ile birlikte değerlendirilmiştir. Bu amaç doğrultusunda, Bulancak ilçesinde tarım sektörünün ve işletmelerin mevcut durumu analiz edilerek tarımsal faaliyeti engelleyen faktörler belirlenmeye çalışılarak sektörün bölgesel ve ülke ekonomisine katkı sağlaması amacıyla politika geliştirilmesinin önü açılacaktır.

\section{Metodoloji}

Araştırmanın ana materyalini; Giresun ili Bulancak ilçesinde amaca uygun 10 köyde 1.597 işletmeyi temsil niteliğine sahip örnekleme yolu ile seçilen 134 işletmeden yüz yüze anket yöntemiyle toplanan veriler oluşturmaktadır. Ayrıca çalışmanın materyalinde ilgili kamu kurum ve kuruluşlarının istatistiki verileri ile konuya ilişkin daha önce yapılmış araştırma ve incelemeleri içeren ikincil verilerden de yararlanılmıştır. Araştırmanın verileri 2016-2017 üretim dönemini kapsamaktadır. Çalışma bölgesine ait veriler Giresun İl Tarım Müdürlüğünden temin edilmiştir.

Araştırma alanı olarak, Giresun ilinin Bulancak ilçesi seçilmiştir. Araştırma alanı belirlendikten sonra, Giresun İl Tarım Müdürlüğünün kayıtlarından yararlanılarak araştırmaya konu olan toplam köy sayıları belirlenmiştir. İlçede 2 belde, 62 köy ve 14 mahalle bulunmaktadır. Çiftçi kayıt sistemine 10.774 tarım işletmesi kayıtlıdır. Ana kütleyi oluşturan 2 belde, 62 köy ve 14 mahalleden üretim deseni, topoğrafya, tarım tekniği ve iklim gibi özellikler dikkate alınarak 10 köy gayeli olarak seçilmiştir. Bulancak ilçesinde 10 köyde (Ardahan, Kışla, Küçükdere, Ahurlu, Yeşiltepe, İnece, Eriklik, Tekmezar, Tepeci ve Küçükköy) amaca uygun toplam 1.597 tarım işletmesi bulunmaktadır. Bu işletmeler daha sonra, arazi genişliği kriteri dikkate alınarak sıraya konulmuş ve varyasyon katsayısı hesaplanmıştır. Varyasyon katsayısının yüksek çıkması 
$(\% 82,09)$ ve bölgedeki arazi dağılımının heterojen olması sebebiyle örneklemede tabakalı tesadüfî örnekleme yöntemi kullanılmıştır. Dağılım grafiği çizilmiş ve grafikteki kırılmalar dikkate alınarak, araştırma evreninin oluşturan işletmeler normal dağılım gösterecek şekilde 1-9, 10-27 ve $>27$ olmak üzere 3 gruba (tabakaya) ayrılmıştır. Bu amaçla bölge için \%95 güven aralığında ve ortalamadan \%5 sapma (t tablo değeri=1,96) ile yapılması gereken anket sayısı belirlenmiştir. Örneklemede "Neyman Yöntemi” kullanılmış ve örnek hacmi aşağıdaki formül ile tespit edilmiştir.

$n=\frac{\left(\sum N_{h} S_{h}\right)^{2}}{\left(\sum N_{h}\right)^{2} D^{2}+\left(\sum N_{h}\left(S_{h}\right)^{2}\right)} \quad$ Essitlik(1)

$D=\frac{x^{*} 0,05}{t} \quad$ (Çiçek ve Erkan, 1996).

Varyasyon katsayısı $\mathrm{CV}=(\mathrm{S} / \overline{\mathrm{x}}) * 100$ formülü kullanılarak hesaplanmıştır. Formülde $\mathrm{CV}=$ varyasyon katsayısın, $\mathrm{S}=$ Verilerin standart sapmasını, $\overline{\mathrm{x}}=$ verilerin aritmetik ortalamasını ifade etmektedir (Çiçek ve Erkan, 1996).

Formülde;

$n=\ddot{o r n e k ~ h a c m i n i,}$

$N_{h}=$ h'ncı tabakaya ait örnekleme çerçevesindeki işletme sayısını,

$S_{h}=$ h'incı tabakadaki verilerin standart sapmasinl,

$S_{h}{ }^{2}=h^{\prime}$ 'ncı tabakadaki verilerin varyansinı,

$N=$ Örnekleme çerçevesindeki toplam işletme sayısını,

$\overline{\mathrm{x}}=$ verilerin aritmetik ortalamasını,

$t=$ güven aralı̆̆ için tablo değerini,

$D=$ ortalamadan $\% 5$ oranında sapmayt ifade etmektedir.

Belirlenen örnek hacminin tabakalara dağılımında;

$\mathrm{n}_{\mathrm{i}}=\frac{N_{h} S_{h}}{\sum N_{h} S_{h}} n \quad$ Eşitlik (2) formülünden yararlanılmıştır.

\%95 güven aralığında \%5 sapma dikkate alınarak yapılan hesaplamalar sonucunda Eşitlik 1 kullanılarak örnek genişliği 134 olarak belirlenmiştir. Anket uygulanacak 134 tarım işletmesi her gruptan tabaka büyüklüklerine orantılı olacak şekilde Eşitlik 2 kullanılarak dağıtılmış ve Tablo 1'de verilmiştir. 
Tablo 1: Bulancak İlçesindeki İşletmelere Ait Örnek Sayısı

\begin{tabular}{|c|c|c|c|c|c|c|c|}
\hline $\begin{array}{c}\text { Tabaka } \\
\text { no }\end{array}$ & $\begin{array}{c}\text { Tabaka } \\
\text { sinır1 (da) }\end{array}$ & $\overline{\mathrm{X}}(\mathrm{da})$ & $\begin{array}{c}\text { Tabakadaki işletme } \\
\text { sayıs1 }\left(\mathrm{N}_{\mathrm{h}}\right)(\mathrm{adet})\end{array}$ & $\mathrm{S}_{\mathrm{h}}$ & $\mathrm{N}_{\mathrm{h}} \mathrm{S}_{\mathrm{h}}$ & $\mathrm{N}_{\mathrm{h}} \mathrm{S}_{\mathrm{h}}{ }^{2}$ & $\mathrm{n}$ \\
\hline I & $1-9$ & 5,45 & 647 & 2,25 & $1.455,75$ & $3.275,44$ & $\mathbf{2 5}$ \\
\hline II & $10-27$ & 16,67 & 724 & 4,94 & $3.576,56$ & $17.668,21$ & $\mathbf{6 2}$ \\
\hline III & $28-+$ & 40,10 & 226 & 11,98 & $2.707,48$ & $32.435,61$ & $\mathbf{4 7}$ \\
\hline Genel & --- & 15,44 & --- & 12,67 & --- & --- & --- \\
\hline Toplam & --- & --- & 1.597 & --- & $7.739,79$ & $53.379,25$ & $\mathbf{1 3 4}$ \\
\hline
\end{tabular}

Araştırmada anket yoluyla elde edilen verilerin değerlendirilmesinde frekans dağılımı ve yüzde gibi tanımlayıcı istatistiklerden yararlanılmıştır. İşletmelerin bitkisel ve hayvansal üretim faaliyetlerine ait veriler, işletme büyüklük grupları için ayrı ayrı değerlendirilip, tüm işletmeler ortalaması olarak da ortaya konulmuştur. Elde edilen veriler durum tespiti amaciyla hem sayısal olarak ortaya konulmuş hem de istatistiksel analizler ile işletme büyüklükleri (gruplar) bakımından karşılaştırmalı olarak değerlendirilmiştir. Çalışma sonucu elde edilen verilerle Bulancak ilçesindeki tarım işletmelerinin işletme büyüklükleri itibariyle mevcut durumunun tespit edilmesi, yapısal farklıl1kların ve sorunların belirlenmesi ve bu sorunların ortadan kaldırılması ya da en aza indirilmesi için gerekli önerilerin ortaya konulması istenmektedir.

\section{Bulgular ve Tartışma}

İncelenen işletmelerin işletme başına düşen ortalama işletme arazisi, işletme arazinin tasarruf şekli ve parçalılık durumu Tablo 2'de verilmiştir. Toplam mülk araziden ortağa ve kiraya verilen arazinin çıkarılmasıyla bizzat işletilen arazi hesaplanmıştır.

Tablo 2: İncelenen İşletmelerde Ortalama Arazi Mevcudu (da), Tasarruf Şekli ve Parçalılık Durumu

\begin{tabular}{|c|c|c|c|c|c|c|}
\hline & \multicolumn{4}{|c|}{ İşletme grupları } \\
\hline & & & $\begin{array}{l}\text { I. Grup } \\
(25)\end{array}$ & $\begin{array}{l}\text { II. Grup } \\
(62)\end{array}$ & $\begin{array}{l}\text { III. Grup } \\
(47)\end{array}$ & $\begin{array}{c}\text { İşl. Ort. } \\
\text { (134) }\end{array}$ \\
\hline \multirow{3}{*}{ 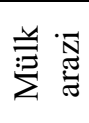 } & Toplam mülk arazi & da & 7,37 & 19,61 & 51,61 & 28,55 \\
\hline & Mülk araziden ortağa ve kiraya verilen & da & 2,35 & 3,85 & 5,81 & 4,26 \\
\hline & Bizzat işletilen arazi & da & 5,02 & 15,76 & 45,80 & 24,29 \\
\hline \multicolumn{2}{|c|}{ İşletme arazisi } & da & 5,02 & 15,76 & 45,80 & 24,29 \\
\hline \multicolumn{2}{|c|}{ Parsel say1s1 } & adet & 2,74 & 5,77 & 13,88 & 8,05 \\
\hline
\end{tabular}

İşletmelerde işletme başına düşen ortalama işletme arazisi 1. grupta 5,02 da, 2. grupta 15,76 da, 3. grupta 45,80 da, genel ortalamasinda 24,29 da'dır. Samsun ilinde yapılan bir çalışmada, ortalama işletme büyüklügü 29,84 da olarak hesaplanmıştır (Kurt, 2020). Konya ili Çumra ilçesinde yapılan başka bir çalışmada, işletme başına düşen arazi miktarı 251,43 da olarak bulunmuştur (Kaya, 2020). Türkiye'de 2001 genel tarım sayımı sonuçlarına göre ise ortalama işletme büyüklüğü 61 da'dır (TUİK, 2019). Araştırma bölgesindeki ortalama işletme büyüklüğünün Samsun ilinde bulunan işletme büyüklügüne yakın Konya ili Çumra ilçesi ve Türkiye ortalamasının ise çok altında olduğu söylenebilir. İncelenen işletmelerde toplam işletme arazisinin 28,55 da'1 mülk arazisinden oluşurken, 4,26 da'1 ortağa ve kiraya verilmektedir. İşletmelerde kiraya ve ortağa tutulan arazi bulunmamaktadır. Tablo 2'den de görülebileceği gibi incelenen işletmelerde işletme büyüklüğü arttıkça ortalama parsel sayılarında da bir artış söz konusu olmaktadır. 2016 yılı TÜİK verilerine göre, Türkiye'de işletme başına düşen tarım arazisi 
parça sayısı 5,9 adettir (tuik.gov.tr, 2019). Benzer şekilde findık işletmelerinin küçük ve parçalı olduğu da bildirilmektedir (İslam, 2018). Elde edilen sonuçlara göre, araştırma alanındaki 3. grup işletmelerde $(13,88$ adet) ve işletmeler genel ortalamasında $(8,05)$ bu oran, Türkiye ortalamasının üzerinde bulunmuştur. İşletmelerin sahip olduğu arazi parsel sayısının çok veya dağınık olması, işletmelerin başarısını etkileyen önemli unsurlardan sayılmaktadır (Öztürk, 2011). Bu durum araştırma alanındaki işletmelerin etkin çalışma koşullarını olumsuz yönde etkileyerek üretimde verimliliğin düşmesine neden olabilir.

İncelenen işletmelerde arazi nevileri olarak; meyvelik arazi, tarla arazisi, sebze arazisi, çayır-mera arazisi, ağaçlık arazi ve nadas saptanmıştır. İşletmelerde arazi nevileri ve dağılımı işletme grupları itibariyle Tablo 3'de verilmiştir.

Tablo 3: İncelenen İşletmelerde İşletme Arazisinin Nevi'lerine Göre Dağ 1 lımı (da/işletme ve \%)

\begin{tabular}{|c|c|c|c|c|c|}
\hline & \multicolumn{4}{|c|}{ İşletme grupları } \\
\hline & & I. Grup (25) & II. Grup (62) & III. Grup (47) & İşl. Ort. (134) \\
\hline \multirow{2}{*}{ Findik } & $\mathrm{da}$ & 4,70 & 14,58 & 39,35 & 21,42 \\
\hline & $\%$ & 93,63 & 92,52 & 85,92 & 88,18 \\
\hline \multirow{2}{*}{ Kivi } & $\mathrm{da}$ & 0,00 & 0,06 & 0,00 & 0,03 \\
\hline & $\%$ & 0,00 & 0,38 & 0,00 & 0,12 \\
\hline \multirow{2}{*}{ Meyve arazisi } & $\mathrm{da}$ & 0,00 & 0,03 & 0,47 & 0,18 \\
\hline & $\%$ & 0,00 & 0,19 & 1,03 & 0,75 \\
\hline \multirow{2}{*}{ Tarla bitkileri } & $\mathrm{da}$ & 0,08 & 0,30 & 4,70 & 1,80 \\
\hline & $\%$ & 1,59 & 1,90 & 10,26 & 7,42 \\
\hline \multirow{2}{*}{ Sebze arazisi } & $\mathrm{da}$ & 0,24 & 0,43 & 0,53 & 0,43 \\
\hline & $\%$ & 4,78 & 2,73 & 1,16 & 1,78 \\
\hline \multirow{2}{*}{$\begin{array}{l}\text { Çayır ve mera } \\
\text { alanı }\end{array}$} & $\mathrm{da}$ & 0,00 & 0,24 & 0,66 & 0,34 \\
\hline & $\%$ & 0,00 & 1,52 & 1,44 & 1,41 \\
\hline \multirow{2}{*}{ Ağaçlık arazi } & $\mathrm{da}$ & 0,00 & 0,05 & 0,09 & 0,05 \\
\hline & $\%$ & 0,00 & 0,32 & 0,19 & 0,22 \\
\hline \multirow{2}{*}{ Nadas } & $\mathrm{da}$ & 0,00 & 0,07 & 0,00 & 0,03 \\
\hline & $\%$ & 0,00 & 0,44 & 0,00 & 0,12 \\
\hline \multirow{2}{*}{ Toplam } & $\mathrm{da}$ & 5,02 & 15,76 & 45,80 & 24,29 \\
\hline & $\%$ & 100,00 & 100,00 & 100,00 & 100,00 \\
\hline
\end{tabular}

İncelenen işletmelerde toplam işletme arazisi ekiliş alanlarının büyük bir kısmını meyve bahçeleri oluşturmaktadır. Meyve bahçelerinin çok büyük bir kısmında findık bulunmaktadır. İşletme arazisi dikiliş alanları içerisindeki fındığın payı \%88,18'dir. Meyve arazilerini sırasıyla $\% 7,42$ ile tarla bitkileri, \%1,78 ile sebze arazisi, \%1,41 ile çayır-mera alanı, \%0,22 ile ağaçlık arazi ve $\% 0,12$ ile nadas alanları izlemektedir. İşletmelerin ekili arazilerinin $\% 92,54$ 'ünün fiziksel yapısı eğimli ve geriye kalan \%7,46'sının ise düzlüktür.

Herhangi bir kooperatife üye olan işletmelerin oranı \%42,54'dür. İşletme grupları itibariyle bakıldığında; 1 . grup işletmelerin $\% 48$ 'i, 2. grup işletmelerin $\% 24,19$ 'u ve 3 . grup işletmelerin ise $\% 63,83$ 'ü herhangi bir kooperatife üye olduklarını bildirmişlerdir. Kars ilinde yapılan bir araştırmada, işletmelerin \%41,9'unun kooperatife üye oldukları tespit edilmiştir (Demir vd., 2014). Kooperatife üye olan işletmelerin \%3,09'u kooperatifin çok iyi, \%36,84'ü iyi, 
\%39,94'ü orta düzeyde iyi işlediğini ifade ederken, \%20,13’ü ise yetersiz olduğunu belirtmişlerdir. $\mathrm{Bu}$ durum işletme grupları itibariyle incelenecek olursa; 1. grup işletmelerin $\% 33,33$ 'ü, 2. grup işletmelerin $\% 40$ '1, 3. grup işletmelerin ise $\% 43,33$ 'ü kooperatifin iyi ya da çok iyi işlediğini düşünmektedir. İşletmeler genel ortalamasına göre; kooperatife üye olan işletmelerin \%4,64'ü kooperatifin kendileri için çok fazla, \%61,25'i normal, \%27,49’u az derecede yararlı olduğunu ifade ederken, $\% 6,62$ 'si ise kooperatiften hiç yarar görmediklerini belirtmişlerdir. Tarımsal faaliyetleri geliştirmek için işletmelerin \%34,33'ünün bir pazarlama, üretim, hayvancılık vs. birliğe/kooperatife katılmaları çok ilgilerini çekerken, \%44,78'inin orta, \%11,19'unun az ve \%9,70'inin ise hiç ilgisini çekmemektedir. İşletme grupları itibariyle incelenecek olursa; 1 . grup işletmelerin $\% 32$ 'sinin, 2. grup işletmelerin $\% 27,42$ 'sinin ve 3 . grup işletmelerin ise \%44,68'inin tarımsal faaliyetlerini geliştirmek için bir pazarlama, üretim, hayvancılık vs. birliklere katılmayı çok istedikleri görülmüştür.

İşletmelerin \%36,57'si son üç yılda ana üretimdeki ürün veriminin azalmakta olduğunu ifade ederken, \%9,70'i aynı, \%1,49'u artmakta ve \%52,24'ü ise verimin dalgalı bir seyir izlediğini belirtmiştir. Bu durum işletme grupları itibariyle incelendiğinde; 1. grup işletmelerin \%84'ünün, 2. grup işletmelerin $\% 87,1$ 'inin ve 3 . grup işletmelerin ise $\% 88,81$ 'inin ürün veriminin azalmakta ya da dalgalı olduğu görülmüştür. Eğimli arazilerde bulunan işletmelerde orta derecede toprak erozyonu olduğu ve işletmelerin \%87,32'sinin toprak erozyonuna karşı tedbir almadığ belirlenmiştir. İşletmelerin \%10,27'si arazi küçüklügü, \%16,45'i az verimli toprak, \%1,56's1 erozyon sorunu, \%35,46's1 don olay1, \%30,53'ü bitki hastalık ve zararl1ları, \%3,89'u yetersiz yağış/kuraklık, \%1,23’ü yetersiz gübreleme ve \%0,61'i ise budama yetersizliği gibi nedenlerle son üç y1l içerisinde ana üretimdeki ürün veriminin azalmakta ya da dalgalı olduğunu ifade etmişlerdir. İşletmelerin \%0,52'si mevcut arazilerinde verimi artırmak için kompost, \%11,03’ü ahır gübresi, \%32,52'si kimyasal gübre, \%26,13'ü düzenli budama, \%29,20'si hastalık ve zararlılarla mücadele, \%0,60’1 sulama yapmaktadır. Arazi verimliliğini artırmak için 1. grup işletmelerin \%35,59'u, 2. grup işletmelerin \%32,73'ü ve 3. grup işletmelerin \%30,60’1 kimyasal gübre kullanmaktadır. Düzenli budama yapanların oranı; 1. grup işletmelerde $\% 22,03$, 2. grup işletmelerde $\% 26,67$ ve 3 . grup işletmelerde $\% 27,81$ 'dir. Hastalık ve zararlılarla mücadele edenlerin oranı ise 1 . grup işletmelerde $\% 23,73,2$. grup işletmelerde $\% 30,91$ ve 3 . grup işletmelerde ise $\% 29,85$ 'dir. Düzce ilinde yapılan bir araştırmada, üreticilerin verimi artırmada sulama, gübreleme ve ilaçlama gibi işlemlerin uygulanma düzeylerinin oldukça yüksek olduğu belirlenmiştir (Yılmazgil, 2016).

Son iki sene boyunca, herhangi bir ürünün hastalıklardan, zararlılardan ve yabanc1 otlardan ya da benzeri şeylerden etkilenme düzeyi işletmelerin $\% 3,05$ 'inde pek çok, $\% 53,97$ 'sinde çok fazla, \%35,12'sinde orta, \%4,73'ünde az düzeyde gerçekleşirken, işletmelerin \%3,13'ünde ise hiç görülmemiştir. İşletme grupları itibariyle bakıldığında; 1 . grup işletmelerin \%54,55'inde, 2. grup işletmelerin $\% 49,18$ 'inde, 3 . grup işletmelerin ise $\% 60$ ' 1 nda son iki sene boyunca herhangi 
bir ürünün hastalıklardan, zararlılardan ve yabancı otlardan ya da benzeri şeylerden etkilenme düzeyi çok fazladır.

Tablo 4: İncelenen İşletmelerde Hayvan Sayısı (\%)

\begin{tabular}{|l|r|r|r|r|}
\hline & \multicolumn{4}{|c|}{ İşletme grupları } \\
\cline { 2 - 5 } & I. Grup (25) & II. Grup (62) & III. Grup (47) & İșl. Ort. (134) \\
\hline Süt ineği (yerli) & 8,20 & 11,18 & 7,46 & 9,32 \\
\hline Süt ineği (melez) & 14,75 & 13,53 & 7,46 & 11,63 \\
\hline Süt ineği (saf) & 0,00 & 0,00 & 0,50 & 0,18 \\
\hline Büyükbaş hayvan (yerli) & 1,64 & 5,88 & 27,86 & 12,80 \\
\hline Büyükbaş hayvan (melez) & 26,23 & 4,12 & 24,88 & 15,53 \\
\hline Büyükbas hayvan (saf) & 0,00 & 1,17 & 1,98 & 1,24 \\
\hline Koyun & 0,00 & 58,24 & 6,97 & 29,38 \\
\hline Tavuk & 49,18 & 5,88 & 22,39 & 19,74 \\
\hline At & 0,00 & 0,00 & 0,50 & 0,18 \\
\hline Toplam & 100,00 & 100,00 & 100,00 & 100,00 \\
\hline
\end{tabular}

İşletmelerin \%50,7'sinde büyükbaş hayvanı, \%29,38'inde küçükbaş hayvanı, \%19,74'ünde kümes hayvanı ve \%0,18'inde ise binek hayvanı yetiştirilmektedir (Tablo 4). Hayvan yetiştiriciliği yapan işletmelerin \%42,54'ü son üç yıl içerisinde önemli hayvan kayıpları yaşadığını belirtirken, \%57,46'sı böyle bir kayıp yaşamadıklarını ifade etmişlerdir. Hayvan kayıplarının \%50,64'ünün hayvan hastalıkları, \%19,40'ının selden dolayı ve \%29,96'sının ise hırsızlık nedeniyle yaşandığını belirtmişlerdir. 1. grup işletmelerin \%48'i son üç yıl içerisinde önemli bir hayvan kaybı yaşadığını ve bunun da en önemli sebebinin hırsızlık (\%39) olduğunu ifade etmişlerdir. 2. grup işletmelerin \%24,19’u önemli hayvan kayıpları yaşadığını ve bunun da en önemli nedeninin hayvan hastalıkları $(\% 53,23)$ olduğunu belirtmişlerdir. 3. grup işletmelerin ise $\% 63,83$ 'ü önemli hayvan kayıpları yaşadığını ve bunda da en önemli nedenin hayvan hastalıkları (\%55) olduğunu ifade etmişlerdir.

Hayvancılık faaliyetlerinde karşılaşılan en önemli kısıt işletmelerin \%38,39’u tarafından girdi (yem, ilaç vb.) pahalılığı olarak görülmüştür. Bunu sırasıyla; çayır/mera alanı yetersizliği $(\% 21,23)$, ürünlere düşük fiyat verilmesi $(\% 19,79)$, hayvan hastalıkları $(\% 15,13)$, hayvan pazarının olmaması $(\% 4,53)$ ve su azlığı $(\% 0,93)$ izlemektedir. 1 . grup işletmelerde hayvancılık faaliyetlerinde karşılaşılan en önemli kısıt girdi pahalılığı (\%30) ve hayvan hastalıkları (\%30), 2. grup işletmelerde girdi pahalılığ $(\% 39,29)$ ve 3 . grup işletmelerde ise girdi pahalılığ $(\% 41,67)$ olarak tespit edilmiştir. Erzurum ili Narman ilçesinde yapılan bir çalışmada, üreticilerin işletmelerindeki en büyük sıkıntı olarak hastalıkları $(\% 25,7)$ ve yem fiyatlarının pahalı $(\% 22,6)$ olmasını gösterdikleri belirtilmiştir (Koçyiğit vd., 2018). Şeker vd., (2012) üreticilerin işletmelerinde yaşanan en büyük sıkıntının $\% 48,7$ ile yemin pahalı olması ve $\% 42,7$ 'si ise uygun kredi desteklerinin sağlanmasını istediklerini bildirmişlerdir.

İşletmelerin \%9,70'inde arı kovanı bulunmaktadır. Arıcılık faaliyetleri kapsamında işletmelerin karşılaştığı en önemli kısıtların başında elverişsiz hava koşulları $(\% 24,32)$ 
gelmektedir. Bunu sırasıyla; arı hastalıkları $(\% 22,98)$, arıc1lıla ilgili destek hizmetlerinin yetersizliği $(\% 16,40)$, modern arı kovanlarının yüksek maliyeti $(\% 12,16)$, çiçek kaynağı $(\% 9,27)$, arıcılık faaliyetlerinin geliştirilmesine yönelik kredi eksikliği $(\% 6,57)$, oğul arıların kaçması $(\% 2,89)$, modern arı kovanı eksikliği $(\% 2,70)$, pazarlama sorunu $(\% 1,35)$, ana/kraliçe arının kalitesi $(\% 1,35)$ izlemektedir. Her üç işletme grubunda da elverişsiz hava koşulları arıcılık faaliyetlerinde karşılaşılan en önemli kısıtların başında gelmektedir.

Tablo 5: İncelenen İşletmelerde Tarım Faaliyetlerinde Karşılaşılan Başlıca Kısıtlar (\%)

\begin{tabular}{|l|c|c|c|c|}
\hline & \multicolumn{4}{|c|}{ İşletme grupları } \\
\cline { 2 - 5 } & I. Grup (25) & II. Grup (62) & III. Grup (47) & İşl. Ort. (134) \\
\hline Düşük satış fiyatı & 18,11 & 20,08 & 18,99 & 19,33 \\
\hline İş gücü yetersizliği & 11,02 & 11,07 & 11,81 & 11,32 \\
\hline Pazarlama sisteminin eksikliği & 8,66 & 4,84 & 4,22 & 5,34 \\
\hline Pahalı tarım girdileri & 14,17 & 16,61 & 18,14 & 16,69 \\
\hline Hastalık zararları & 8,65 & 13,84 & 12,66 & 12,46 \\
\hline Arazi küçüklügü & 7,09 & 5,54 & 5,06 & 5,66 \\
\hline Makina/teçhizat yetersizliği & 3,15 & 1,04 & 3,38 & 2,25 \\
\hline Sermaye azlı̆̆1 & 3,15 & 4,15 & 5,49 & 4,43 \\
\hline Düşük verim & 10,24 & 13,15 & 10,55 & 11,70 \\
\hline Tarımsal yayım hizmetlerin eksikliği & 0,79 & 2,42 & 2,11 & 2,01 \\
\hline Su kkisıtlılı̆̆1 & 0,79 & 0,69 & 0,00 & 0,47 \\
\hline Toprak sorunları & 7,09 & 5,88 & 6,33 & 6,26 \\
\hline Ulaşım eksikliği & 7,09 & 0,69 & 1,26 & 2,08 \\
\hline Toplam & 100,00 & 100,00 & 100,00 & 100,00 \\
\hline
\end{tabular}

İşletmelerde tarım faaliyetlerinde karşılaşılan en önemli kısıtlar sırasıyla; düşük satış fiyatı $(\% 19,33)$, pahalı tarım girdileri $(\% 16,69)$, hastalık zararları $(\% 12,46)$, düşük verim $(\% 11,70)$, işgücü yetersizliği $(\% 11,32)$ şeklinde sıralanabilir. İşletme grupları itibariyle bakıldığında; her üç işletme grubunda da tarım faaliyetlerinde karşılaşılan en önemli kısıt düşük satış fiyatı olarak bulunmuştur (Tablo 5). Karaman ili merkez ilçede, üreticilerin bitkisel üretimde karşılaştıkları en önemli sorunların başında ürettikleri ürünlerin düşük fiyata satılması geldiği belirlenmiş̧tir. Diğer sorunlar ise, girdi ve mazot fiyatlarının yüksekliği, sulama sorunları ve üretim maliyetlerinin yüksek olması olarak belirtilmiştir (Alüftekin, 2007). Tokat ilinde yapılan diğer bir çalışmada ise, üreticilerin karşılaştıkları sorunlar önem sıralamasına göre; girdilerin pahalı olması, hastalık ve zararlılar, pazarlama yetersizliği, piyasaların belirsiz oluşu, finansman yetersizliği, teknik bilgi eksikliği, işgücü yetersizliği ve diğer faktörler şeklinde sıralanmıştır (Gebeloğlu vd., 2011).

Tablo 6: İncelenen İşletmelerde Tarım Faaliyetlerini Geliştirmek İçin Yapılan İşlemler (\%)

\begin{tabular}{|l|c|c|c|c|}
\hline \multirow{2}{*}{} & \multicolumn{4}{|c|}{ İşletme grupları } \\
\cline { 2 - 5 } & I. Grup (25) & II. Grup (62) & III. Grup (47) & İşl. Ort. (134)) \\
\hline Daha fazla bilgilenmeye çalışıyorum & 42,32 & 37,40 & 34,26 & 37,22 \\
\hline İl/İlçe tarım görevlilerine danışıyorum & 26,92 & 31,30 & 31,48 & 30,55 \\
\hline Kaliteli girdiler alıyorum & 7,69 & 4,58 & 5,56 & 5,50 \\
\hline Kredi alıyorum & 0,00 & 5,34 & 6,48 & 4,74 \\
\hline Kooperatife/birliğe üye oldum & 11,54 & 8,40 & 13,89 & 10,91 \\
\hline Akraba/arkadaşlardan borç alıyorum & 1,92 & 7,63 & 4,63 & 5,51 \\
\hline Hiçbir şey yapmiyorum & 1,92 & 1,53 & 0,00 & 1,07 \\
\hline Diğger & 7,69 & 3,82 & 3,70 & 4,50 \\
\hline Toplam & 100,00 & 100,00 & 100,00 & 100,00 \\
\hline
\end{tabular}


Tarım faaliyetlerini geliştirmek için yapılan en önemli işlemler sırasıyla; daha fazla bilgilenmeye çalışmak $(\% 37,22)$, tarım il/ilçe görevlilerine danışmak $(\% 30,55)$ ve kooperatife/birliğe üye olmaktır $(\% 10,91)$. Her üç işletme grubunda da tarım faaliyetlerini geliştirmek için işletmelerin daha fazla bilgilenmeye çalıştıları ve tarımsal faaliyetleri geliştirmek için hevesli oldukları görülmüştür (Tablo 6).

Tablo 7: İncelenen İşletmelerde Kamu Kuruluşlarından Alınan Tarım Destek Hizmeti Türleri * (\%)

\begin{tabular}{|l|c|c|c|c|}
\hline \multirow{2}{*}{} & \multicolumn{4}{|c|}{ İşletme grupları } \\
\cline { 2 - 5 } & I. Grup (25) & II. Grup (62) & III. Grup (47) & İşl. Ort. (134) \\
\hline Doğrudan gelir desteği (fındık alan bazlı) & 90,78 & 90,75 & 95,66 & 92,48 \\
\hline Sera tesisi & 6,90 & 15,30 & 6,33 & 10,59 \\
\hline Sertifikalı tohum desteği & 81,25 & 65,30 & 65,43 & 68,32 \\
\hline Gübre ve mazot desteği & 90,33 & 95,10 & 94,88 & 94,13 \\
\hline Hayvancılık desteği & 0,00 & 21,95 & 21,75 & 17,78 \\
\hline Arıcılık desteği & 0,00 & 3,66 & 3,78 & 3,02 \\
\hline Yem bitkileri desteği & 3,44 & 0,00 & 0,00 & 0,64 \\
\hline Aş1lama desteği & 0,00 & 3,66 & 3,54 & 2,94 \\
\hline Süt teşvik prim desteği & 15,80 & 13,66 & 13,54 & 14,02 \\
\hline Pazarlama desteği sağlanması & 6,90 & 0,00 & 3,78 & 2,61 \\
\hline Tarımsal kredi & 12,35 & 12,64 & 15,43 & 13,56 \\
\hline Tarımsal yayım hizmetleri & 6,90 & 3,32 & 9,10 & 6,02 \\
\hline Suni tohumlama & 12,35 & 12,66 & 13,78 & 13,00 \\
\hline
\end{tabular}

*Birden fazla seçenek işaretleme yapılmıştır.

Bu soruda işletmeler kamu kuruluşlarından alınan tarım destek hizmet türlerini sıralarken birden fazla cevap vermişlerdir. Kamu kuruluşları tarafından sağlanan tarımsal desteklerden en önemlileri sırasıyla; doğrudan gelir desteği $(\% 92,48)$, gübre ve mazot desteği $(\% 94,13)$ ve sertifikalı tohum desteğidir $(\% 68,32)$ (Tablo 7). Konya ili Çumra ilçesinde yapılan bir çalışmada işletmelerin tamamının gübre ve mazot desteği kullandıkları tespit edilirken, bu desteği sırasıyla prim desteği, sertifikalı tohum kullanım desteği, yem bitkileri desteği, iyi tarım uygulamaları desteğin ve organik tarım desteğinin (ÇATAK) takip ettiği görülmüştür (Düğmeci, 2020). İşletmelerin \%0,75'i tarım yayım uzmanlarının köylerini haftada bir ziyaret ettiğini ifade ederken, \%6,'s1 ayda bir, \%45,87'si mevsimsel ve \%32,31'i yılda bir kez ziyaret ettiğini bildirmiştir. Tarım yayım uzmanlarının köylerini hiç ziyaret etmediğini belirten işletmelerin oranı ise \%15,07'dir. Her üç işletme grubunda da tarım yayım uzmanları işletmeleri mevsimsel olarak ziyaret etmektedir.

Tablo 8: İncelenen İşletmelerde Tarımla İlgili Sorunları Çözme Yolları (\%)

\begin{tabular}{|l|c|c|c|c|}
\hline \multirow{2}{*}{} & \multicolumn{3}{|c|}{ İşletme grupları } \\
\cline { 2 - 5 } & $\begin{array}{c}\text { I. Grup } \\
(25)\end{array}$ & $\begin{array}{c}\text { II. Grup } \\
(62)\end{array}$ & $\begin{array}{c}\text { III. Grup } \\
(47)\end{array}$ & $\begin{array}{c}\text { İşl. Ort. } \\
(134)\end{array}$ \\
\hline Arkadaşlarıma/meslektaşlarıma soruyorum & 25,40 & 19,41 & 13,85 & 18,58 \\
\hline Bilgili çiftçilere soruyorum & 25,40 & 24,12 & 25,38 & 24,80 \\
\hline Tarım teşkilatı uzmanları gelirse onlara soruyorum & 19,05 & 14,71 & 22,31 & 18,19 \\
\hline Tarım teşkilatını ziyaret ediyorum & 4,75 & 16,47 & 15,38 & 13,90 \\
\hline Girdi sağlayıcılara soruyorum & 14,29 & 19,41 & 18,46 & 18,12 \\
\hline Araştırmacılara soruyorum & 4,76 & 1,17 & 2,31 & 2,24 \\
\hline Diğer & 6,35 & 4,71 & 2,31 & 4,17 \\
\hline
\end{tabular}




\begin{tabular}{|ccc|c|c|c|c|}
\hline Toplam & & & 100,00 & 100,00 & 100,00 & 100,00 \\
\hline \multirow{2}{*}{ Tarımla } & \multirow{2}{*}{ ilgili sorunları işletmelerin } & $\% 24,80$ 'i & bilgili çiftçilere, & $\% 18,58$ 'i
\end{tabular}
arkadaşlarına/meslektaşlarına, \%18,19'u tarım teşkilatı uzmanları gelirse onlara, \%18,12'si girdi sağlayıcılara, \%13,90'ı tarım teşkilatını ziyaret ederek ve \%2,24'i ise araştırmacılara sormaktadır. Geriye kalan \%4,17'si ise bunların dışında bir çözüm yolu aramaktadır. 1. grup işletmeler tarımla ilgili sorunlarını çözerken ilk sırada bilgili çiftçilere ve arkadaşlarına danışırken, 2. grup ve 3. grup işletmeler ise bilgili çiftçilere danışmaktadır (Tablo 8). Samsun ili Bafra ilçesinde yapılan bir çalışmada, işletme sahipleri bilgiye ihtiyaç duydukları tarımsal faaliyetlerle ilgili sorunlarını daha çok komşularından, büyük çiftçilerden ve bilgisine güvendikleri arkadaşlarına danışarak çözmektedirler (Hazneci ve Kızılaslan, 2017). Özdemir ve Kan (2020) Kırşehir ilinde tarım işletmeleri ile ilgili yaptıkları çalışmada ise, işletme yöneticilerinin tarımsal faaliyetlerin yönetimi ve organizasyonunu dışarıdan hiçbir bilgi talep etmeden kendi içinde deneyimleri ile oluşturduğu bilgilerle hareket ederek yürüttüğü sonucuna ulaşmışlardır.

Ürünlerini satarken işletmelerin \%29,68'i düşük satış fiyat1, \%26,97'si yüksek üretim maliyetleri, \%15,71'i depolama tesislerinin eksikliği, \%8,90’1 kötü yol koşulları, \%7,75'i düşük kaliteli ürün, \%5,05'i pazar yerinin uzaklığı ve \%5,94'ü diğer sorunlarla (sınırlı pazar sayısı, talep yetersizliği, paketleme eksikliği, taşıma araçlarının eksikliği) karşılaşmaktadır. Her üç işletme grubunda da tarımsal ürünler satılırken düşük satış fiyatı ve yüksek üretim maliyetleri karşılaşılan en önemli sorunların başında gelmektedir.

İşletmelerin \%29,06'sında üzümsü meyveler, \%13,57'sinde örtüaltı sebze yetiştiriciliği, \%13,05'inde çeviz, \%11,61'inde kivi, \%6,84'ünde diğer meyveler (armut, elma, kiraz vb.), $\% 6,70$ 'inde üzüm, $\% 6,67$ 'sinde mantar, $\% 4,76$ 'sinda patates, $\% 4,09$ 'unda fasulye, $\% 2,92$ 'sinde lavanta ve $\% 0,73$ 'ünde yem bitkileri gibi tarımsal alternatif ürünler üretilmektedir. 1. grup işletmelerde örtüaltı sebze yetiştiriciliği üretilen alternatif tarımsal ürünler arasında ilk sırada yer alırken, 2. grup ve 3. grup işletmelerde ise üzümsü meyveler ilk sırada yer almaktadır. Alternatif tarımsal ürünlerin üretilmesinde işletmelerin \%27,47'si toprak veya arazi yapısı, \%24,09'u girdi temini, \%21,61'i pazarlama, \%12,66's1 sermaye yetersizliği, \%6,90’1 alet-makine yetersizliği, $\% 4,10$ ’u bilgilendirilme azlığı, \%2,65'i kredi bulma ve \%0,52'i diğer zorluklarla karşılaşmaktadırlar. Her üç işletme grubu için de toprak veya arazi yapısı, girdi temini ve pazarlama olanakları alternatif üretimlerin yapılmasında karşılaşılan en önemli zorluklardır.

İşletmelerin \%91,04'ü köyünde kırsal turizm faaliyetlerinin yapılmasını isterken, \%8,96'sı istememektedir. İşletme grupları itibariyle; 1. grup işletmelerin \%80'i, 2. grup işletmelerin $\% 88,71$ 'i ve 3 . grup işletmelerin ise tamamı işletmelerinde kırsal turizm faaliyetlerinin yapılmasını istediklerini beyan etmişlerdir. İşletmelerin \%3,76'sı köyünün kırsal turizm potansiyelinin çok iyi olduğunu düşünürken, \%23,34'ü iyi, \%43,59'u orta, \%21,09'u zayıf ve $\% 8,22$ 'si ise yetersiz olduğunu ifade etmektedir. 1. grup işletmelerin $\% 36$ 's1, 2. grup 
işletmelerin $\% 40,98$ 'i ve 3 . grup işletmelerin ise \%51,07'si köylerinde kırsal turizm potansiyelinin orta düzeyde olduğunu beyan etmişlerdir. Köyünde kırsal turizm faaliyetleri yapıldığı takdirde evinin bir odasını ya da binasını pansiyonculuk yapmak üzere dizayn etmek isteyen işletmelerin oran $\% 65,67$ 'dir. Bu oran 1 . grup işletmelerde $\% 52$ iken, 2. grup işletmelerde $\% 62,90$ ve 3 . grup işletmelerde ise $\% 76,60$ olarak bulunmuştur.

\section{Sonuç ve Öneriler}

Araştırma sonuçlarına göre, incelenen işletmelerde ortalama işletme arazisi 1. grupta 5,02 $\mathrm{da} /$ işletme, 2 . grupta $15,76 \mathrm{da} /$ işletme, 3 . grupta $45,80 \mathrm{da} /$ işletme, işletmeler genel ortalamasında 24,29 da/işletme'dir. İşletme büyüklüğü arttıkça işletmelerin ortalama parsel sayılarında da artış söz konusu olmaktadır. İşletmelerde arazi özellikleri bakımından ortaya çıkan en büyük sorunlardan birisi arazilerin parçalı olmasıdır. $\mathrm{Bu}$ durum, işletmelerdeki mevcut üretim kaynaklarının ve alet-makinaların kullanım verimliliğini olumsuz yönde etkilemektedir. Aynı zamanda işçilik maliyetlerini artırmakta ve tedarikini de zorlaştırmaktadır. Bunun için öncelikle tarım arazilerinin parçalanmasını önleyici gerekli düzenlemelerin yapılması ve arazi toplulaştırma çalışmalarına ağırlık verilmesi önerilmektedir.

İncelenen işletmelerde işletme arazisini oluşturan arazi nev'ileri içerisinde her üç grupta da meyve arazisi ilk sırada yer almaktadır. Meyve bahçelerinin çok büyük bir kısmında fındık bulunmaktadır. İşletmelerin ekili-dikili arazilerinin fiziksel yapısı eğimlidir. İşletmelerin alanları 1. ve 3. grup işletmelerde orta verimli, 2. grup işletmelerde ise az verimlidir. Herhangi bir kooperatife üye olan işletmelerin oranı $\% 42,54$ 'dür. Kooperatiflerin işletilmesi ve kooperatiften yararlanma durumuna göre işletmelerde kararsızlık görülmektedir. Son üç yılda ana üretimdeki ürün verimi tüm işletme gruplarında önemli oranda azalmakta ya da dalgalı bir seyir izlemektedir. Ana üretimdeki ürün veriminin azalmasının ya da dalgalı olmasının sebebini ise her üç gruptaki işletmelerde don olayı, bitki hastalık ve zararlılarından kaynaklandığını belirtmişlerdir. Ayrıca işletmelerin büyük çoğunluğu sulama yapmamaktadır (sulama yapan işletmelerin oranı \%0,56). İşletmeler arazi verimliliğini artırmak için kimyasal gübre, hastalık ve zararlılarla mücadele ve düzenli budama yapmaktadırlar. Bu durum işletmelerin verimliliği artırma gayretinde olduğunu göstermektedir.

Yapılan araştırmada işletmelerin \%50,7'sinde büyükbaş hayvanı, \%29,38'inde küçükbaş hayvanı, \%19,74'ünde kümes hayvanı ve \%0,18'inde ise binek hayvanı yetiştirilmektedir. Hayvan yetiştiriciliği yapan işletmelerin \%42,54'ü son üç y1l içerisinde önemli hayvan kayıpları yaşadığını ve bunun da en önemli nedeninin hayvan hastalıkları olduğunu ifade etmişlerdir. Hayvancılık faaliyetlerinde karşılaşılan en önemli kısıtın girdi (yem, ilaç vb.) pahalılığ ve hayvan hastalıkları olduğu tespit edilmiştir. İşletmelerin \%9,70'inde arı kovanı bulunmakta olup, arıcılık 
faaliyetleri kapsamında her üç işletme grubunda da en önemli kısıt elverişsiz hava koşulları $(\% 24,32)$ olarak bulunmuştur.

İşletmelerde tarım faaliyetlerinde karşılaşılan en önemli kısıtlar sırasıyla; düşük satış fiyatı, pahalı tarım girdileri, hastalık zararları, düşük verim ve işgücü yetersizliği şeklinde sıralanmıştır. İşletmeler tarım faaliyetlerini geliştirmek için ise daha fazla bilgilenmeye çalıştığını, tarım il/ilçe görevlilerine danıştığını, kooperatife/birliğe üye olduğunu, kaliteli girdiler aldığını, akraba ve arkadaşlarından borç aldığını ve kredi kullandığını belirtmişlerdir. Kamu kuruluşlarından sağlanan tarımsal destek hizmetlerinin içerisinde her üç işletme grubunda da doğrudan gelir desteği, gübre ve mazot desteği ilk sırada yer almaktadır. Her üç işletme grubunda da tarım yayım uzmanlarının işletmeleri mevsimsel olarak ziyaret ettiği tespit edilmiştir. Tarımla ilgili sorunlar çözülürken 1. grup işletmelerin bilgili çiftçilere ve arkadaşlarına/meslektaşlarına, 2. grup ve 3. grup işletmelerin ise bilgili çiftçilere danıştı̆̆ görülmektedir. Bu durumda bilgili çiftçiler öne çıkmaktadır.

Her üç işletme grubunda da tarımsal ürünler satılırken düşük satış fiyatı ve yüksek üretim maliyetleri karşılaşılan en önemli sorunların başında gelmektedir. İncelenen işletmelerde ağırlıklı olarak üzümsü meyveler, örtüaltı sebze yetiştiriciliği, çeviz, kivi ve diğer meyveler yetiştirilmektedir. Her üç işletme grubu için de toprak veya arazi yapısı, girdi temini ve pazarlama olanakları alternatif üretimlerin yetiştirilmesinde karşılaşılan en önemli zorluklardır.

İşletmelerin \%91,04'ü köyünde kırsal turizm faaliyetlerinin yapılmasını istediklerini beyan etmişlerdir. Her üç işletme grubunda köylerinde kırsal turizm potansiyelinin orta düzeyde olduğunu belirtmiştir. Köyünde kırsal turizm faaliyetleri yapıldığı takdirde evinin bir odasını ya da binasını pansiyonculuk yapmak üzere dizayn etmek isteyen işletmelerin oranı 1. grup işletmelerde $\% 52$, 2. grup işletmelerde $\% 62,90$ ve 3 . grup işletmelerde ise $\% 76,60$ 'dır.

Eko turizmin tüm çeşitleri ile birlikte alternatif ve kültür turizmi açısından büyük bir potansiyele sahip olan bölgenin turizmde istediği gelişmeyi sağlayabilmesi için yeterli maddi kaynak, sağlanarak, belirli plan ve program dahilinde tanıtım çalışmaları yapması gerekmektedir. Alternatif tarımsal ürünlerin üretilmesinde, birçok işletmede geniş bir çeşitlilikte yerel tarımsal ve hayvansal ürünler üretilmektedir. Üreticilerin bir kısmı üretilen ürünlerin pazarlamasını ve satışını gerçekleştirirken, büyük çoğunluğu zaten sınırlı miktarda olan ürünleri kendi bünyelerinde değerlendirdikleri için pazarlama ve satışa yönelik herhangi bir çalışma yürütmemektedir. Yöresel ürünlerin marka değer kazanması, üretim miktarı ve kalitesinin artması için, makine ekipman desteklemeleri artırılarak, markalaşma ve pazarlama tekniklerine ağırlık verilmeli mutfak kültürünün tanıtımı etkin şekilde gerçekleştirilmelidir.

Erozyonu azaltan uygun arazi kullanım ve yönetimleri uygulanmalıdır. Bu kapsamda hafif eğimli arazilerde mekanizasyona imkan veren teraslama yöntemleri uygulanmalıdır. Çalışma alanındaki tarım topraklarında verimin artırılabilmesi için, toprak analizlerine dayalı 
gübrelemeye önem verilmesi, toprağın organik madde kapasitesini artıracak uygulamaların yapılması, sertifikalı fidan/tohumluk kullanılması, kültürel bakım işlemlerinin yerinde ve zamanında uygulanmasına özen gösterilmelidir.

Bölgede modern tarımsal üretim teknikleri hakkında çiftçilerin bilgi eksikliği giderilmelidir. Bu bağlamda, tarım kuruluşları, araştırma enstitüleri, üniversiteler ve sivil toplum örgütleri arasında bozulmayacak nitelikte çalışma kanalları güçlü bir şekilde devam ettirilmelidir. Yörede son yıllarda yetiştiriciliği yaygınlaşan kivi ve diğer meyve türlerinin üretim tekniği ve özellikle pazarlama sorunları giderilerek yeni üretim alanlarının açılması konusunda üreticiye destek verilmelidir. Ayrıca çiftçiyi kırsal alanda tutacak sosyal etkileşimler ile diğer donatıların da sağlanması veya geliştirilmesinin önemli olduğu düşünülmektedir. Çünkü çiftçilik, dünyada son yıllarda saygınlığı ve gelir düzeyi gittikçe artan bir meslek dalıdır.

Yazar Katkıları: Saha araştırmasının gerçekleştirilmesinde Malik Arsal KÖSE ve Ali TURAN, elde edilen verilerin analizinde Derya ÖZTÜRK, araştırma sonuçlarının yorumlanmasında Derya ÖZTÜRK ve Ali İSLAM önemli katkılar sağlamışlardır.

Çıkar Beyanı: Yazarlar arasında çıkar çatışması bulunmamaktadır. Bu çalışma Ordu Üniversitesi Bilimsel Araştırma Projeleri Komisyonunca kabul edilen A-1803 no'lu proje kapsamında desteklenmiştir.

Teşekkür: Saha çalışmalarında bizlere değerli zamanlarını ayırarak misafirperverlik gösteren ve içtenlikle sorularımızı yanıtlayarak bilgilerini paylaşan tüm yöre üreticilerimize katkılarından dolayı teşekkür ederiz.

\section{Kaynakça}

Akıncı, İ., Topakcı, M. ve Çanakçı, M. (1997). Antalya bölgesi tarım işletmelerinin tarımsal yapı ve mekanizasyon özellikleri. Tarımsal Mekanizasyon 17. Ulusal Kongresi 17-19 Eylül 1997, Bildiri Kitabı, s. 45-57, Tokat.

Aksoyak, Ş., İslam, A., Dede, Ö. ve Gökçe, M. (2001). Ordu ilinin tarımsal yapısı ve findığın ekonomisi. Dünden bugüne Ordu ili (Editör: Öcal Serdar Yıldırım). s.221- 243. Konya.

Alüftekin, N. (2007). Yerel düzeyde ekonomik kalkınmada tarımsal ürün işleyen KOBİ’lerin Rolü: Karaman ili araştırması (Doktora Tezi). Ankara Üniversitesi Fen Bilimleri Enstitüsü, Ankara.

Bülbül, M. (1973). Adana ovası tarım işletmelerinin ekonomik yapısı, finansman ve kredi sorunları. Gıda Tarım ve Hayvancılık Bakanlığı Basın Yayın ve Halkla İlişkiler Dairesi Başkanlığı, Ankara.

Bostan, S. Z., İslam, A. ve Özgüven, A.I. (1997). Ordu ili meyveciliği. Çukurova Üniversitesi Ziraat Fakültesi Dergisi, 12(4), 175-182

Comart, A. (2016). Antalya ili tarım işletmelerinin tarımsal yapı, üretim ve mekanizasyon özelliklerinin belirlenmesi (Yüksek Lisans Tezi). Akdeniz Üniversitesi Fen Bilimleri Enstitüsü, Antalya. 
Çiçek, A. ve Erkan, O. (1996). Tarım ekonomisinde araştırma ve örnekleme yöntemleri. Gaziosmanpaşa Üniversitesi Ziraat Fakültesi Yayınları No:12, Ders Notları Serisi No:6, Tokat.

Demir, P., Aral, Y. ve Sarı̈zkan, S. (2014). Kars İli süt sığırcılık işletmelerinin sosyo-ekonomik yapısı ve üretim maliyetleri. Yüzüncü Yı1 Üniversitesi Veteriner Fakültesi Dergisi, 25 (1), 1-6

Düğmeci, H.Y. (2020). Yağllk ayçiçeği üreten tarım işletmelerinin ekonomik analizi; Konya ili Çumra ilçesi örneği (Yüksek Lisans Tezi). Selçuk Üniversitesi Fen Bilimleri Enstitüsü, Konya.

Esengün, K. (1990). Tokat ilinde meyve yetiştiriciliği yapan işletmelerin ekonomik durumu ve işletme sonuçlarını etkileyen faktörlerin değerlendirilmesi üzerinde bir araştırma (Doktora Tezi). Ege Üniversitesi Fen Bilimleri Enstitüsü, Bornova-İzmir.

Gebeloğlu, N., Cangi, R., Edizer, Y., Sayıl1, M. ve Yağcı, A. (2011). Tokat ili yaş meyve ve sebze sektörü rekabet analizi. Tokat Merkez Sebze Ürünleri Tarımsal Üreticiler Birliği Yayın No: 1 , Tokat

Gün, A. ve Aksoy Dengiz, B. (2006). Buldan ilçesi tarımsal ürün deseninin genel bir değerlendirmesi. Buldan Sempozyumu, 23-24 Kasım 2006. Denizli.

Güneş, E. (2004). Tarım işletmelerinde kredi taleplerinin doğrusal programlama yöntemiyle belirlenmesi "Kırşehir ili Merkez ilçesi tarım işletmeleri araştırması". Tarımsal Ekonomi Araştırma Enstitüsü Yayınları, Ankara.

Hazneci, E. ve Kızılaslan, H. (2017). Samsun ili Bafra ilçesinde sulama birliği çiftçi ilişkileri ve çiftçilerin sulama suyu kullanım karakteristikleri. Anadolu Tarım Bilimleri Dergisi, 32(1), 23-34

İslam, A. ve Turan, A. (2006). Türkiye'de organik findık yetiştiriciliğinin mevcut durumu. Türkiye III. Organik Tarım Sempozyumu, 482-499.

İslam, A. (2013). Kivi yetiştiriciliği ve ekonomisi. Tarım Gündem Dergisi, 21, 35-39

İslam, A. (2018). Hazelnut culture in Turkey. Akademik Ziraat Dergisi 8(2), 176-184.

Kasap, A., Demir, A. ve Dilmaç, M. (1997). Tokat ilinde tarımda makineleşmenin genel yapısı ve sorunları üzerine bir araştırma. Tarımsal Mekanizasyon 17. Ulusal Kongresi 17-19 Eylül 1997, Bildiri Kitabı, s. 39-44, Tokat.

Kaya, E. (2020). Çerezlik kabak üretimi yapan tarım işletmelerinin ekonomik faaliyet sonuçları ve nispi karlılığı: Konya ili Çumra ilçesi örneği (Yüksek Lisans Tezi). Selçuk Üniversitesi Fen Bilimleri Enstitüsü, Konya.

Keleş, İ. (2015). Çumra ilçesi tarım işletmelerinin tarımsal yapısı ve mekanizasyon özelliklerinin belirlenmesi (Yüksek Lisans Tezi). Selçuk Üniversitesi Fen Bilimleri Enstitüsü, Konya.

Kızılaslan, H. ve Doğan, H.G. (2013). AB ve Türkiye'de tarım sektöründe örgütlenme ve üretici birlikleri. Sosyal Bilimler Araştırmaları Dergisi, 8(1), 146-159

Koçyiğit, R., Yanar, M. ve Aydın, R. (2018). Sığırcılık işletmelerinde hayvan sağlı̆̆ı, veteriner sağllk hizmetleri ve yetiştirici memnuniyeti ve beklentileri: Erzurum ili Narman ilçesi örneği. Kahramanmaraş Sütçü İmam Üniversitesi Tarım ve Doğa Dergisi, 21(2), 203208

Kurnaz, V. (2020). Organik bitkisel üretim tercihinde etkili olan faktörler: Ankara ili araştırması (Yüksek Lisans Tezi). Ankara Üniversitesi Fen Bilimleri Enstitüsü, Ankara.

Kurt, Y. A. (2020). Samsun ili Çarşamba ilçesi örtü altı sebze yetiştiricilerinin kullandıkları bilgi kaynaklarının belirlenmesi ve tarımsal yayım açısından değerlendirilmesi (Yüksek Lisans Tezi). Ondokuz Mayıs Üniversitesi Fen Bilimleri Enstitüsü, Samsun. 
Özden, A. ve Armağan, G. (2005). Aydın ili tarım işletmelerinde bitkisel üretim faaliyetlerinin verimliliklerinin belirlenmesi. Tarım Ekonomisi Dergisi, 11(2), 111-121.

Özdemir, H. Ö. ve Kan, M. (2020). Tarım işletmelerinin yönetiminde kullanılan tarımsal bilgi kaynakları: Kırşehir ili örneği. Türk Tarım ve Doğa Bilimleri Dergisi, 7(2), 500-509

Özkan, G. ve Kadağan, Ö. (2019). Bursa ili tarımsal potansiyelinin geliştirilmesine yönelik bir değerlendirme. Turkish Studies, 14(2), 503-522

Öztürk, D. (2011). Fındık yetiştiriciliğinin ekonomik analizi ve alternatif tarla-bahçe ürünlerine göre kârlılığının belirlenmesi üzerine bir araştırma (Samsun ili Çarşamba ve Terme ovası örneği) (Doktora Tezi). Gaziosmanpaşa Üniversitesi Fen Bilimleri Enstitüsü, Tokat.

Öztürk, D. ve Akçay, Y. (2010). Güney Marmara bölgesinde çeltik üretiminin genel bir değerlendirmesi. Gaziosmanpaşa Üniversitesi Ziraat Fakültesi Dergisi, 27 (2), 61-70

Someran, H. (1999). Tokat ili Merkez ilçede meyve yetiştiriciliği yapan işletmelerin ekonomik analizi (Yüksek Lisans Tezi). Gaziosmanpaşa Üniversitesi Fen Bilimleri Enstitüsü, Tokat.

Şeker, İ., Tasalı, H. ve Güler, H. (2012). Muş ilinde sığır yetiştiriciliği yapılan işletmelerin yapısal özellikleri. Fırat Üniversitesi Sağlık Bilimleri Veteriner Dergisi, 26(1), 09-16

Turhan, Ş., Vural, H. ve Erdal, B. (2013). Bursa tarımının sosyo-ekonomik yapısının analizi. Uludağ Üniversitesi Ziraat Fakültesi Dergisi, 27(1), 27-38.

TUIK (2019, Mayıs). Türkiye İstatistik Kurumu. Erişim Adresi: http://www.tuik.gov.tr

Yıldırım, İ. (1991). Van ilinin tarımsal üretim potansiyeli ve ürün deseninin genel bir değerlendirilmesi. Yüzüncü Y1l Üniversitesi Veteriner Fakültesi Dergisi, 1(3), 112-130

Yılmaz, H., Demircan, V. ve Dernek, Z. (2006). Isparta ilinin tarımsal yapısı, üretimi ve gelişme potansiyeli, Süleyman Demirel Üniversitesi Ziraat Fakültesi Dergisi, 1(2), 1-16

Yılmazgil, Y. A. (2016). Arazi kirası, kullanımı ve arazi kaynaklarının korunması ilişkilerinin analizi: Düzce ili örneği (Yüksek Lisans Tezi). Ankara Üniversitesi Fen Bilimleri Enstitüsü, Ankara. 